\title{
An occupational health exposure study in Iron Industry of Mandi Gobindgarh, Punjab, India
}

\author{
Manoj Kumar \\ Assistant Professor, Centre for Public Health, Panjab University, Chandigarh, India
}

\begin{abstract}
Introduction: The World Health Organization estimates occupational health risks as the tenth leading cause of morbidity and mortality. The burden of disease from selected occupational risk factors amounts to $1.5 \%$ of the global burden in terms of Disability Adjusted Life Years (DALY). The World Health Report 2002, has reported that occupational risk factors account for a number of morbid conditions globally, including $37 \%$ back pain, $16 \%$ hearing loss, $13 \%$ chronic obstructive lung disease, $11 \%$ asthma, $10 \%$ injuries, $9 \%$ cancer, and $2 \%$ leukemia.
\end{abstract}

Methods: A Case-control study was conducted in "Industrial town" and "reference town".

Results: According to Standard Occupational Classification, 2000 the study subjects were categorized and it was found that most of the subjects comes under Skilled Trades \& Occupations followed by Elementary Occupations in industrial town as compared to reference town where number were non significant. Results of multivariate logistic regression showed that after controlling the confounding variables, cough $(O R=1.59,95 \%$ CI 1.21-2.12, $P=0.001$ ), phlegm (OR=1.56, 95\% CI 1.17-2.07, $P=0.003)$, wheeze (OR=1.50, 95\% CI 1.04-2.17, $P=0.03)$, chronic bronchitis $(O R=2.23,95 \%$ CI 1.10-4.53 $P=0.03)$ and obstructive defects $(O R=1.86,95 \% C I$ 1.43-2.42, $P=0.001$ ) were significantly higher amongst the residents of Mandi Gobindgarh. Adult population of Mandi Gobindgarh, has significantly more chronic respiratory morbidity as compared to that of Morinda.

Conclusion: It is concluded that in Industrial town level of higher exposure for TSP in the ambient air is responsible for the poor occupational health status in adults of Industrial town.

Key words: <Occupations, Workers, Exposure, Obstruction, Restriction >

\section{Introduction}

Hazardous work, working conditions, and environment fail to maintain homeostasis results in death or severe disability. Up to the 1980s, governments did not pay major attention to occupational health in developing countries, including India ${ }^{1}$. The Bhopal Gas Tragedy, in 1984, was the turning point in the history of health and safety in India. It was time for the government to think deeply and review the existing legislative measures, for the upliftment of the occupational health situation in India. However, all the services remain grossly underutilized because of inadequate strategies, policies, and the lack of a proper monitoring mechanism, for occupational workers. The present study reviews the fact that Inaction or Destruction of Demands, Use of Power, Appeal to the existing bias of the system, and Exportation and Flexibility of the workers are some of the main reasons for the alarming situation of the Occupational Health Policy (OHP) in India ${ }^{2}$.

In order to evaluate the risk aspects due to air pollution at the general population levels, several factors have to be considered, i.e., exposure dose, biological effect and proportion of the exposed population. The results of these studies are difficult to interpret because of a variety of limitations mostly regarding exposure assessment and handling of co-factors ${ }^{3}$.

Chronic obstructive pulmonary disease (COPD) is one of the leading causes of morbidity and mortality both in the industralised and the developing countries. The burden of this respiratory disease worldwide is expected to increase and have an impact on the individual and the society ${ }^{33}$. The disease contribute an immense in this country as well. ${ }^{21,37}$

An attempt has been made in the past to estimate the gross burden of chronic obstructive pulmonary disease (COPD) in India. ${ }^{21}$ The median values of prevalence rates from published studies were 5.0 percent in male and 2.7 percent in female population ${ }^{21}$. These results also substantiated by a multi-centric epidemiological study from India. ${ }^{35}$ But the role of air pollutants has not been clearly studied from India.

This study was aimed to evaluate the effects of air pollutants on respiratory morbidity among adults in representative samples of two populations one each in industrial and a non-industrial town of Punjab.

\section{Methods}

In Mandi Gobindgarh main occupational exposure was due to Iron Industry. Whereas Morinda, which was taken, as reference area is free from any industry. 


\section{Study Design}

A Case-Control study was conducted in the "exposed" and the "reference" population with a view to collect the data pertaining to socio-demographic factors, occupational history, life style (including smoking), respiratory symptoms and lung functions. Ambient air quality data were assessed for a period of two year.

The sample size was approximately 1000 for the exposed and the reference populations. According to cluster sampling scheme, two colonies were selected in each of the towns. Interview was carried out based on a structured questionnaire. The questionnaire on respiratory symptoms was tailored on the questions listed by the British Medical Research Council, UK ${ }^{12}$, American Thoracic Society ${ }^{2}$, and International Study of Asthma and Allergies in Childhood (ISAAC) schedules ${ }^{3}$. The questionnaire pertained to the questions on socio-economic characteristics, household environment, respiratory symptoms, smoking history, residence and occupational history. To assess the socio-economic status, modified Kuppuswami scale ${ }^{25}$ was used. Data collection was undertaken from January 2000 to December 2001. It consisted of interview and physical examination of the individual and the air sampling at both the towns.

\section{Interview Schedule}

Occupational health surevy was conducting by using an interview schedule. After completion of the interview, the physical examination was carried out and measurements were made for, height and weight. Spirometry.

Forced vital capacity $(\mathrm{FVC})$, forced expiratory volume in first second $\left(\mathrm{FEV}_{1}\right)$, peak expiratory flow (PEF) and $\mathrm{FEV}_{1} / \mathrm{FVC} \%\left(\mathrm{FEV}_{1}\right.$ as a percentage $\left.\mathrm{FVC}\right)$ were measured. Prevalence of obstructive disease and restrictive diseases, were calculated ${ }^{1}$ from lung functions, i.e., $\mathrm{FVC}, \mathrm{FEV}_{1}$, and $\mathrm{FEV}_{1} / \mathrm{FVC}$.

\section{Exposure Assessment}

Air quality monitoring was done by the High Volume Air Sampler (HVS) (Envirotech APM 460), every week, for particulate matter less then ten micron size $\left(\mathrm{PM}_{10}\right)$, TSP, NOx, SOx and $\mathrm{O}_{3}$. Weekly sampling by the Organic Vapour Sampler (OVS) (Envirotech APM 850) was done for CO.

\section{Statistical Analysis}

Chi-square test was used to test significant difference, in the categorical and t-test for quantitave variables. T-test was used to compare means values of years of residence, smoking duration and smoking index. Odds ratio and $95 \%$ confidential intervals for residence in industrial town were estimated using binary logistic regression analysis in SPSS programme.

\section{Results}

\section{Exposure}

Only the level of Total Suspended Particulate matter (TSP) was observed more than permissible limit in Mandi Gobindgarh. Level of monthly means of Total Suspended Particulate matter (TSP) in Mandi Gobindgarh ranged from 662.1 to $1125.1 \mu \mathrm{g} / \mathrm{m}^{3}$ while in Morinda it ranges from 143.5 to $599.9 \mu \mathrm{g} / \mathrm{m}^{3}$. Levels of all the pollutants were higher in Mandi Gobindgarh than in Morinda.

Daily and yearly variations of all the parameters were under permissible limit except total suspended particulate matter (TSP) that was more than permissible limit in Mandi Gobindgarh. Levels of all the pollutants were higher in Mandi Gobindgarh compared to these in Morinda.

Meteorological data obtained from Patiala observatory showed higher temperature in the summer months of year 2001 as compared to year 2000 is a reason for dispersion of pollutants that might have lead to lower level of pollution in the year 2001 as compared to 2000. Average relative humidity was more while average wind velocity was comparatively less in the year 2001 as compared to 2000.

\section{Socio-economic status of the study population}

For the household survey, 1003 subjects were selected from the exposed and 1001 from the reference town. There was equal distribution of men and women in the two sample groups, only than having age more then 20 years were sampled.

The level of higher socio-economic status, current smoking, passive smoking, biomass fuel use, household environment such as inadequate light, inadequate ventilation and dampness, moderate to severe dust exposure, immigrants and factory workers were higher in Mandi Gobindgarh. Therefore, prevalence of respiratory morbidities was compared according to socio-economic status, smoking, biomass fuel use, dust exposure, immigrants and factory workers in both the towns. 


\section{Prevalence of chronic respiratory morbidities}

It was found that prevalence of cough and phlegm in Mandi Gobindgarh were $25.6 \%$ and $25.2 \%$ respectively in males, which were significantly higher as compared to Morinda.

It was found that prevalence of breathlessness and wheezing in Mandi Gobindgarh were 21.9\% and $10.9 \%$ in males, which were significantly higher as compared to Morinda.

Prevalence of chronic bronchitis and asthma was significantly higher in males of Mandi Gobindgarh (25.6\% and $5.1 \%$ respectively) as compared to $15.6 \%$ and $1.6 \%$ respectively at Morinda.

Obstructive abnormalities in males and females of Mandi Gobindgarh was 28.8\% and 26.4\% respectively, which was significantly higher as compared to $14.9 \%$ and $12.9 \%$ in Morinda respectively.

The population characteristics in Mandi Gobindgarh were not similar to that of Morinda with respect to socio-economic status, smoking, use of biomass fuel, ethnically, and length of residence in the town. Some of these characteristics particularly smoking, use of biomass fuel and occupation have been shown to be associated with chronic respiratory morbidities. Therefore, prevalence of respiratory morbidity was compared in stratified analysis in smokers and non smokers users of biomass fuel and non users of biomass fuel and among occupational socio-economic, migrant and resident groups. The prevalence of respiratory morbidities was significantly higher in Mandi Gobindgarh even in non-smokers, non-biomass fuel users, among those having higher socio-economic status, among non industrial workers and local residents compared to Morinda. Confounding in these variables was evaluated in multivariate analysis.

After controlling the effect of age, sex, socioeconomic status, smoking, biomass fuel use, inadequate lighting, inadequate ventilation, dampness, residence duration, dust exposure, factory workers and migrant population by using binary logistic regression models on individual symptoms it was observed that cough $(\mathrm{OR}=1.59$ 95\% CI 1.21-2.12, $\mathrm{P}=0.001)$. It was significant for cough, phlegm, dyspnoea, wheeze, asthma, chronic bronchitis and obstructive defects were significant associated with poor ambient air quality. Whereas tuberculosis and restrictive defects were not significant in the area of poor ambient air quality. Smoking, biomass fuel, duration of residence and migration were independently associated with respiratory morbidity. The ambient air quality was poorer in Mandi Gobindgarh due to high TSP and could be responsible for high prevalence of cough, phlegm, dysponea, wheeze, chronic bronchitis and obstructive spirometric patterns was also observed in Mandi Gobindgarh as compared to Morinda, towns with lower level of air pollution. Similarly association of poor air quality with chronic respiratory morbidity has observed in other cross-sectional studies.

\section{Discussion}

The acute effects of air pollution have stimulated the interest of epidemiologists and clinicians, and several studies were published focusing on the associations between adverse respiratory symptoms and concentrations of air pollutants. Time series studies have shown that air pollution is associated with increased hospital admissions and mortality due to cardiorespiratory diseases as pre-existing conditions aggravate with rise in air pollution. However, long term effects of ambient air pollution in causing chronic respiratory problems such as chronic bronchitis and asthma, have been less clear.

Air quality was monitored in the study area for $\mathrm{PM}_{10}, \mathrm{TSP}, \mathrm{NO}_{\mathrm{x}}, \mathrm{SO}_{\mathrm{x}}, \mathrm{CO}$ and $\mathrm{O}_{3}$ by using standard methods prescribed by Bureau of Indian Standards (BIS) ${ }^{15,16,17,18,19}$. Concentrations of air pollutants are compared with the standards of ambient air quality that have been set for Indian climate by CPCB, World Health Organisation (WHO) and United State of Environment Protection Agency (USEPA). In Mandi Gobindgarh level of $\mathrm{PM}_{10}, \mathrm{TSP}, \mathrm{NO}_{\mathrm{x}}, \mathrm{SO}_{\mathrm{x}}, \mathrm{CO}$ and $\mathrm{O}_{3}$ were significantly higher as compared to Morinda. Only the level of SPM was more than the permissible limits of CPCB and USEPA in Mandi Gobindgarh.

Only the level of Total Suspended Particulate matter (TSP) was observed more than permissible limit in Mandi Gobindgarh. Level of monthly means of Total Suspended Particulate matter (TSP) in Mandi Gobindgarh ranged from 662.1 to $1125.1 \mu \mathrm{g} / \mathrm{m}^{3}$ while in Morinda it ranges from 143.5 to $599.9 \mu \mathrm{g} / \mathrm{m}^{3}$. Levels of all the pollutants were higher in Mandi Gobindgarh than in Morinda.

Level of TSP in Mandi Gobindgarh ranged from 506.0 to $1308.5 \mu \mathrm{g} / \mathrm{m}^{3}$ while in Morinda it ranged from 114.0 to $480.0 \mu \mathrm{g} / \mathrm{m}^{3}$ except one peak of $796.9 \mu \mathrm{g} / \mathrm{m}^{3} . \mathrm{PM}_{10}$ is considered to be more sensitive parameter than TSP. Concentration of $\mathrm{PM}_{10}$ in Mandi Gobindgarh were also mostly more than the permissible limit of CPCB. Level of monthly mean of $\mathrm{PM}_{10}$ range from 50.2 to $242.6 \mu \mathrm{g} / \mathrm{m}^{3}$ in Mandi Gobindgarh while in Morinda it ranges from 54.7 to $90.5 \mu \mathrm{g} / \mathrm{m}^{3}$. The level of air pollutants in study area during year 2001 was less as compared to year 2000. Reason for this decrease in the level of TSP in 2001 could be due to the decrease in the number of industries in the year 2001 as compared to the previous years as strict enforcement against pollution spreading industries forced some of the industries to close down.

The prevalence of cough, phlegm, breathlessness and wheezing in Mandi Gobindgarh were $25.6 \%$, $25.2 \%, 21.9 \%$ and $10.9 \%$ in males, and $14.5 \%, 13.6 \%, 32.3 \%$ and $10.0 \%$ in females respectively whereas prevalence of these symptoms in Morinda were $14.4 \%, 12.6 \%, 15.0 \%$ and $6.4 \%$ in males, and $9.9 \%, 10.6 \%$, $24.9 \%$ and $5.2 \%$ among females respectively. Kamet et al., (1987) has reported the prevalence of chronic cough 
in the range of $1.7 \%$ to $5.1 \%$ and dyspnoea range from $3.2 \%$ to $7.2 \%$ in Mumbai. Chronic cough was $12 \%$ and $11.2 \%$ in Parel and Lava whereas dyspnoea was $53 \%$ and $13 \%$ respectively.

In this study prevalence of self reported asthma in Mandi Gobindgarh was $5.1 \%$ and $2 \%$ among males and females respectively whereas in Morinda it was $2 \%$ and $0.8 \%$ respectively. Jindal S.K. et al., (2001) have reported asthma prevalence of $3.9 \%$ in urban males, $3.9 \%$ in rural males, and $1.3 \%$ in both urban and rural females from north India ${ }^{21}$. Gupta D. et al., (2001) have reported asthma in $3.3 \%$ children who were not exposed to environmental tobacco smoke ${ }^{13}$. According to ISSAC study (1998) asthma prevalence was $2.8 \%$ among children in Chandigarh.

In this study chronic bronchitis prevalence was $19.6 \%$ among males and $9.6 \%$ among females in Mandi Gobindgarh and 5.4\% and 3.0\% respectively in Morinda. Jindal S. K. et al. (2001) reviewed 14 studies, to estimate the gross burden of chronic obstructive pulmonary disease (COPD) ${ }^{21}$. The median values of different prevalence rates were $5 \%$ in male and $2.7 \%$ in female population. In three urban areas of Mumbai prevalence of chronic bronchitis ranged from $2.3 \%$ to $4.5 \%$ (Kamet et al., 1987). Bakke et al., (1991) has reported chronic bronchitis ${ }^{4}$ in $5.4 \%$.

In this study spirometery standards developed by Jindal S.K. and Wahi P.L., (1990) for north India population were used ${ }^{20}$. The prevalence of obstructive defect was observed in $29.0 \%$ in males and $14.7 \%$ among females in Mandi Gobindgarh and 24.2\% and 12.6\% among males and females respectively in Morinda. Mild obstructive defects were much more common. In Mandi Gobindgarh males and females were having mild obstructive defect but moderate to severe defect was in $7.6 \%$ and $5.9 \%$ respectively. In Morinda, the prevalence of moderate to severe obstructive defect was observed in $2.8 \%$ and $5.4 \%$ among males and females respectively. According to study done by Bakke P. S. et al. (1991), spirometric patterns ( $\mathrm{FEV}_{1} / \mathrm{FVC}<0.7$ and $\mathrm{FEV}_{1},<80 \%$ of predicted values) was observed in $4.5 \%$ of the population ${ }^{5}$.

Prevalence of self reported tuberculosis among males and females was $2.9 \%$ and $1.4 \%$ in Mandi Gobindgarh whereas in Morinda it was $2.0 \%$ and $0.1 \%$ respectively. The prevalence of tuberculosis was reported as $0.4 \%$ in India.

Chhabra S.K. et al. (2001) also found that subjects those who were exposed to poor ambient air quality due to high level of SPM had poor lung function tests in Delhi ${ }^{8}$. Similarly studies by Detels R. et. al. ${ }^{11}$ (1981) and Pope C.A. et al. ${ }^{31}$ (1991) have also reported association of poor air quality and higher respiratory morbidity in USA. Kamat et $\mathrm{al}^{22}$. (1987) showed a higher morbidity with raised levels of air pollution in 3 urban and a rural community of Mumbai. In the respective 4 areas standardised prevalence were: for dyspnoea $7.3 \%, 6 \%$, $3.2 \%$ and $5.5 \%$; for chronic cough $5.1 \%, 2.7 \%, 1.7 \%$ and $3.3 \%$; for chronic bronchitis $4.5 \%, 4.5 \%, 2.3 \%$ and $5.0 \%$.

In present study association between poor ambient air quality was found with cough $(\mathrm{OR}=1.59$, 95\%CI: $1.21-2.12, \mathrm{P}=0.001)$ and phlegm $(\mathrm{OR}=1.56,95 \% \mathrm{CI} 1.17-2.07, \mathrm{P}=0.003)$. This is supported by study of Wong C.M. et al., (1989), which shows a significant effects of air pollution on morning cough (OR=1.65, 95\%CI: 1.03-2.64), phlegm in morning ( $\mathrm{OR}=1.40,95 \% \mathrm{CI}: 1.03-1.92)$, phlegm day or night ( $\mathrm{OR}=1.63,95 \% \mathrm{CI}$ : $1.10-2.42)$ and phlegm for three months $(\mathrm{OR}=1.70,95 \% \mathrm{CI}$ : $1.13-2.56)$ in nonsmoking women in high polluted area. The odds ratio (OR) for the distinct effect was 1.55, which is consistent with Dockery's statements that the health effects of air pollution observed in the cites of the United States would usually be weak, with a relative risk of less than 2 and often less than 1.5 for typical exposure ${ }^{34}$.

In this study subjects exposed to poor ambient air quality significantly associated with obstructive spirometric patterns $(\mathrm{OR}=1.89,95 \% \mathrm{CI} 1.45-2.45, \mathrm{P}<0.001)$. These results are in accordance to study done by Karita K. et al., (2001) who reported an increase in prevalence of obstructive changes in the peripheral airways among traffic police in Bangkok ${ }^{23}$. Ostro B. D. et al. (1991) found that air borne $\mathrm{H}^{+}$was significantly associated with several indicators of asthma status, including moderate or severe cough and shortness of breath ${ }^{26}$.

Zemp E. et al. (1999), in a cross-sectional study in random population samples of adults at eight study sites in Switzerland reported independent, positive association between annual mean concentrations of $\mathrm{NO}_{2}$, total suspended particulates, and particulates of less than $10 \mu \mathrm{m}$ in aerodynamic diameter $\left(\mathrm{PM}_{10}\right)$ with prevalence of chronic phlegm production, chronic cough or phlegm production, breathlessness at rest during the day, breathlessness during the day or at night, and dysponea on exertion. They found no associations with wheezing without cold, current asthma, chest tightness, or chronic cough. Among never-smokers, the odds ratio $(95 \% \mathrm{CI})$ for a $10 \mu \mathrm{m} / \mathrm{m}^{3}$ increase in the annual mean concentrations of $\mathrm{PM}_{10}$ was 1.35 (1.11 to 1.65) for chronic phlegm production, 1.27 (1.08 to 1.50) for chronic cough or phlegm production, 1.48 (1.23 to 1.78) for breathless during the day, 1.33 (1.14 to 1.55$)$ for breathlessness during the day or night, and 1.32 (1.18 to 1.46) for dyspnoea on exertion. Similar associations were also found for former and current smokers, except for chronic phlegm production. The observed associations remained stable when further control was applied for environmental tobacco smoke exposure, past and current occupational exposures, atopy, and early childhood respiratory infections when restricting the analysis to long-term residents and to non alpine areas, and when excluding subjects with physician-diagnosed asthma ${ }^{35}$. 
Peter J.M. et al. (1999) conducted a ten year prospective cohort study of Southern California children, with a study design focused on four pollutants; ozone, particulate matter, acids, and nitrogen dioxide $\left(\mathrm{NO}_{2}\right)$. Wheeze prevalence was positively associated with levels of both acid $(\mathrm{OR}=1.45 ; 95 \% \mathrm{Cl}, 1.14 .83)$, and $\mathrm{NO}_{2}$ $(\mathrm{OR}=1.54 ; 95 \% \mathrm{Cl}, 1.08-2.19)$ in boys. In the present study dyspnoea $(\mathrm{OR}=1.41,95 \% \mathrm{CI} 1.09-1.78, \mathrm{P}=0.01)$ and asthma $(\mathrm{OR}=2.27,95 \% \mathrm{CI} 1.12-4.59, \mathrm{P}=0.03)$ was significantly associated with poor ambient air quality ${ }^{30}$. Chhabra S.K. et al. (1999), studied the magnitude of the problem of childhood asthma in India and the factors influencing its occurrence. Multiple logistic regression analysis showed that male sex, a positive family history of atopic disorders, and the presence of smokers in the family were significant factors influencing the development of asthma whereas socio-economic class, air pollution (total suspended particulates), and type of domestic kitchen fuel were not associated with asthma ${ }^{8}$.

Chhabra S.K. et al. (2001) compared nonsmoking residents of lower- and higher-pollution zones in Delhi stratified according to socioeconomic levels and sex. Chronic cough, chronic phlegm, and dyspnoea (but not wheezing) were significantly more common in the higher-pollution zone in only some of the strata. Lung functions of asymptomatic nonsmokers were consistently and significantly better among both male and female residents of the lower-pollution zone? .

Several times series studies have shown correlation of air pollution with hospital admission and cardiorespiratory mortality. A study by Pande J N et al., (2002) on outdoor air pollution and emergency room visits at All India Institute of Medical Sciences (AIIMS) in Delhi has show that emergency room visits for asthma, chronic obstructive airway disease (COAD) and acute coronary events increased by $21.30 \%, 24.90 \%$ and $24.30 \%$ respectively on account of higher than acceptable levels of pollutants ${ }^{29}$. The study of Sunyer J et. al., in 1993 showed that sulphur dioxide and black smoke concentrations in the urban air of Barcelona were associated with the number of COPD emergency room admissions in both winter and summer ${ }^{32}$. Burnett R.T. et al. (1995), studied ${ }^{6}$ the association of daily cardiac and respiratory admissions of 168 cases to acute care hospital in Ontario, Canada, with daily levels of particulate sulphates examined over the six year period 1983-1988. A 13 $\mu \mathrm{g} / \mathrm{m}^{3}$ increase in sulphates recorded on the day prior to admission (the 95th percentile) was associated with a $3.7 \%(\mathrm{p}<0.0001)$ increase in respiratory admissions and a $2.8 \%(\mathrm{P}<0.0001)$ increase in cardiac admission. After adjusting for ambient temperature and ozone, similar increased respiratory admissions were observed in the period from April to September (3.2\%) and in the period from October to March (2.8\%). Results of study conducted by Chew E.T. et. al., (1999), shows that ambient air pollutant levels, in particular, those of $\mathrm{SO}_{2}$, TSP and $\mathrm{NO}_{2}$ were consistently associated with emergency room visits for asthma in children ${ }^{7}$. Damia A.D.D. et al. (1999) showed that air pollutants (black smog and $\mathrm{SO}_{2}$ ) correlate significantly with emergency room admissions for asthma $\left(\mathrm{SO}_{2}[\mathrm{r}=0.32]\right.$, black smoke $\left.[\mathrm{r}=0.35]\right)$; however, multiple regression analysis showed that black smoke was the only significantly predicator of weekly visits ${ }^{10}$.

A cross-sectional study was carried out by Kumar R et al. (2004), to estimate the prevalence of chronic respiratory symptoms (cough, phlegm, breathlessness or wheezing) i.e. 27.9 and $20.3 \%$ and obstructive ventilatory defect i.e. 24.9 and $11.8 \%$, in the study and reference towns, respectively. Logistic regression analysis showed that residence in the study town was independently associated with chronic respiratory symptoms (odds ratio $[\mathrm{OR}]=1.5 ; 95 \%$ confidence interval $[\mathrm{CI}]=1.2,1.8 ; \mathrm{p}<0.001$ ) and spirometric ventillatory defects $(\mathrm{OR}=2.4 ; 95 \% \mathrm{CI}=2.0,2.9 ; \mathrm{p}<0.001)$ after controlling for other demographic effects ${ }^{24}$.

This study show that poor ambient air quality at Mandi Gobindgarh was associated with high prevalence of cough, phlegm, dysponea, wheeze, chronic bronchitis, asthma and obstructive but not with tuberculosis and restrictive defects. This study provides further evidence that long-term exposure to air pollution of rather high levels of TSP is associated with higher prevalence of respiratory symptoms in adults.

Finally, the association between chronic respiratory morbidities with air pollution found in this study seems to be causal in nature. Of the pollutants studied, level of total suspended particulate matter (TSP) was higher Mandi Gobindgarh and it is an important contributor in causation of respiratory morbidity and abnormal lung functions. Level of $\mathrm{PM}_{10}, \mathrm{NOx}, \mathrm{SOx}, \mathrm{O}_{3}$ and $\mathrm{CO}$ were also more in Mandi Gobindgarh than Morinda but were below the permissible limit. Air pollutants cause damage to respiratory endothelium Pande J.N. (2002) found that people living in areas with high air pollution have increased levels of soluble intercellular adhesion molecule-1, a marker for endothelial activation. Chronic respiratory morbidities such as chronic bronchitis occur after a prolonged exposure. Most study subjects are permanent residents of the town or are long time migrants to Mandi Gobindgarh. They are exposed to air pollution since industrilisation started in this town about 60-70 years ago. The air pollution levels are alarmingly high in Indian metropolitan towns. ${ }^{34}$ The World Health Organization (1998) estimated 3 million premature deaths per year, mainly in acute and chronic respiratory infections, attributed to exposure to air pollution on a worldwide basis.

It is concluded that in Industrial town level of higher exposure for TSP in the ambient air is responsible for the poor occupational health status in adults of Industrial town. 
We thank the workers of Iron Industry.

\section{Acknowledgments}

\section{References}

[1]. Aggarwal AN, Gupta D, Jindal SK. Development of simple computer program for spirometry interpretation. Journal of Association of Physicians India.2002;50:567-570

[2]. American Thoracic Society. Lung function testing: selection of reference values and interpretative strategies. American Journal of Respiratory Critical Care Medicine. 1991;144:1202-1216.

[3]. Asher MI, Keil U, Anderson, HR et al. Worldwide variation in the prevalence of asthma symptoms, International study of asthma and allergies in childhood (ISAAC). European Respiratory Journal.1998; 12:315-335.

[4]. Bakke P, Eide GE, Hanoa R, Gulsvik A. Occupational dust or gas exposure and prevalence of respiratory symptoms and asthma in a general population. European Respiratory Journal.1991;4:273-276.

[5]. Bakke PS, Baste V, Hanoa R, Gulsvik A. Prevalence of obstructive lung disease in a general population, relation to occupational title and exposure to some air borne agents. Thorax.1991;46:863-870.

[6]. Burnett RT, Dales R, Krewski D, Vincent R, Dann T, Brook JR. Association between ambient particulate sulphate and admission to Ontario Hospitals for cardiac and respiratory diseases. American Journal of Epidemiology.1995;142:15-22.

[7]. Chew FT, Goh DYT, Ooi BC, Saharom R, Hui JKS, Lee BW. Association of ambient air pollution levels with acute asthma exacerbation among children in Singapore.1999;54:320-329.

[8]. Chhabra SK, Gupta CK, Chhabra P, Rajpal S. Risk factors for development of bronchial asthma in children in Delhi. Anal of Allergy and Asthma Immunology.1999;83:385-90.

[9]. Chhabra SK, Chhabra P, Rajpal S, Gupta RK. Ambient air pollution and chronic respiratory morbidity in Delhi. Archives of Environmental Health.2001;56:58-64.

[10]. Damia ADD, Fabregas ML, Tordera MP, Torrero LC. Effects of air pollution and weather conditions on asthma exacerbation. Respiration.1999;66:52-58.

[11]. Detels R, Sayre JW, Coulson AH et al. The UCLA population studies of chronic obstructive respiratory disease. American Review of Respiratory Disease.1981;124:673-680.

[12]. Fletcher C, Peto R, Tinker C, Speizer FE. An eight-year study of early chronic obstructive lung disease in working man in Londan. The natural history of chronic bronchitis and emphysema.1965;11-189.

[13]. Gupta D, Aggarwal AN, Kumar R, Jindal SK. Prevalence of bronchial asthma and association with environmental tobacco smoke exposure in adolescent school children in Chandigarh, North India. Journal of Asthma.2001;38:501-507.

[14]. Health Effect Institute. Air pollution, the automobile and public. National Academic Press, Washington DC.1988;19.

[15]. Indian standard methods for measurement of air pollution (sulphur dioxide). Bureau of Indian Standard.5182.2001;2.

[16]. Indian standard methods for measurement of air pollution (Suspended Particulate Matter). Bureau of Indian Standard, 5182.1999;4.

[17]. Indian standard methods for measurement of air pollution (Nitrogen oxides) (1998). Bureau of Indian Standard.5182.1998;6.

[18]. Indian standard methods for measurement of air pollution. (Carbon monoxide). Bureau of Indian Standard.5182.1999;10.

[19]. Indian standard methods for measurement of air pollution (Ozone). Bureau of Indian Standard. 5182.1986;9.

[20]. Jindal SK and Wahi PL. Pulmonary function laboratory in the tropics. Lung disease in the tropics.1990;523-542.

[21]. Jindal SK, Aggarwal AN, Gupta D. A review of population studies from India to estimate national burden of chronic obstructive pulmonary disease and its association with smoking. Indian Journal of Chest Disease and Allied Sciences.2001;43:139-147.

[22]. Kamat SR, Doshi VB. Sequential health effects study in relation to air pollution in Bombay, European Journal of Epidemiology.1987;3:265-277.

[23]. Karita K, Yano E, Jinsart W, Boudoung D, Tamura K. Respiratory symptoms and pulmonary function among traffic police in Bangkok, Thailand. Archives of Environmental Health.2001;56:467-70.

[24]. Kumar R, Sharma M, Srivastva A, Thakur JS, Jindal SK, Parwana HK. Association of Outdoor Air Pollution with Chronic Respiratory Morbidity in an Industrial Town in Northern India. Archives of Environmental Health.2004;59:471-477.

[25]. Kuppuswami B. Manual of socio-economic status scale (Urban)., Manasayan, 32, Netaji Subhash Marg, Delhi.1981.

[26]. Ostro BD, Michel JL, Mathew BW, Johan CS. Asthmatic responses to airborne acid aerosols. American Journal of Public Health.1991;81:694-702.

[27]. Standard Occupational Classification (SOC). Structure and description of unit groups. Office for national statistics (ONS) London.2000.

[28]. Punjab State Council for Science and Technology. Status Report. Punjab Environment.1995;28-42.

[29]. Pande JN, Bhatta N, Biswas D, et al. Outdoor air pollution and emergency room visits at a hospital in Delhi. Indian Journal of Chest Disease and Allied Sciences. 2002;44: 9-11.

[30]. Peter JM, Avol E, Navidi W. A study of twelve southern Califonia communities with differing levels and types of air pollution. American Journal of Respiratory Critical Care Medicine.1999;159:760-767.

[31]. Pope CA III, Dockery DW, Spengler JD, Raizenne ME. Respiratory health and $\mathrm{PM}_{10}$ pollution. A daily time series analysis. American Review of respiratory Diseases.1991;144: 668-674.

[32]. Sunyer J, Saez M, Murillo C, Castellsague J, Martinez F, Anto JM. Air pollution and emergency room admissions for chronic obstructive pulmonary disease: A 5-year study. American Journal of Epidemiology.1993;137:701-705.

[33]. Viegi G, Di Pede C. Chronic obstructive lung diseases and occupational exposure. Current Opinion on Allergy and Clinical Immunology.2002;2:115-21.

[34]. World Health Organisation. Air quality guidelines for Europe. WHO regional publication series, Geneva.1987;23.

[35]. Wong CM, Hu ZG, Lam TH, Hedley AJ, Peters J. Effects of ambient air pollution and environmental tobacco smoke on respiratory health of non-smoking women in Hong Kong. International Journal of Epidemiology.1999;28:859-864.

[36]. Zemp E, Elsasser S, Schindler C, et al. Long term ambient air pollution and respiratory symptoms in adults. American Journal of Respiratory Medicine.1999;159:1257-1266.

[37]. Jindal SK. Emergence of chronic obstructive pulmonary disease as an epidemic in India. Indian Journal of Medical Research. 2006; 124:619-630.

[38]. Jindal SK, Aggarwal AN, Chaudhry K, Chhabra SK, D'Souza GA, Gupta D, et al. Asthma epidemiological study group. A multicentric study of chronic obstructive pulmonary disease and its relationship with tobacco smoking and environmental tobacco smoke exposure. Indian Journal of Chest Diseases Allied Science. 2006; 48:23-27. 
Table 1. Occupation distributions according to Standard Occupational Classification, 2000 in "exposed" and the "reference" population, Punjab

\begin{tabular}{|c|c|c|c|c|c|}
\hline \multirow[t]{2}{*}{ Major Groups } & \multirow[t]{2}{*}{ Codes } & \multicolumn{2}{|c|}{$\begin{array}{l}\text { Mandi Gobindgarh } \\
(\mathrm{N}=1003)\end{array}$} & \multicolumn{2}{|c|}{$\begin{array}{l}\text { Morinda } \\
(\mathrm{N}=1001)\end{array}$} \\
\hline & & $\begin{array}{c}\text { Male } \\
(\mathrm{N}=501) \text { No. } \\
(\%)\end{array}$ & $\begin{array}{c}\text { Female } \\
(\mathrm{N}=502) \\
\text { No. }(\%)\end{array}$ & $\begin{array}{c}\text { Male } \\
(\mathrm{N}=500) \text { No. } \\
(\%)\end{array}$ & $\begin{array}{c}\text { Female } \\
(\mathrm{N}=501) \mathrm{No} . \\
(\%)\end{array}$ \\
\hline No Work & 0 & $53(10.6)$ & $16(3.2)$ & $57(11.3)$ & $40(7.9)$ \\
\hline Manager \& Senior Officer & 1 & $42(8.4)$ & $5(0.9)$ & $79(15.7)$ & $3(0.6)$ \\
\hline Professional Occupations & 2 & $8(1.6)$ & $5(1.0)$ & $17(3.4)$ & $14(2.8)$ \\
\hline Associate Professionals \& Technical Occupational & 3 & $19(3.8)$ & $1(0.2)$ & $38(7.6)$ & $4(0.8)$ \\
\hline Administrative and secretarial & 4 & $4(0.8)$ & $1(0.2)$ & $12(2.4)$ & $1(0.2)$ \\
\hline Skilled Trades \& Occupations & 5 & $248(49.5)$ & $9(1.8)$ & $134(26.8)$ & $1(0.2)$ \\
\hline Personal Service Occupations & 6 & $18(3.6)$ & $414(82.5)$ & $32(6.4)$ & $420(83.8)$ \\
\hline Sales \& Customer Service Occupations & 7 & $9(1.8)$ & $0(0.0)$ & $27(5.4)$ & $1(0.2)$ \\
\hline Process Plant \& Machine Operatives & 8 & $24(4.8)$ & $0(0.0)$ & $19(3.8)$ & $2(0.4)$ \\
\hline Elementary Occupations & 9 & $76(15.1)$ & $51(10.1)$ & $85(17.0)$ & $15(3.0)$ \\
\hline
\end{tabular}

*Between towns $\mathrm{P}<0.05$

Table 2. Prevalence of spirometric abnormalities in "exposed" and the "reference" population, Punjab

\begin{tabular}{|c|c|c|c|c|c|c|}
\hline \multirow[b]{2}{*}{ Spirometric abnormalities } & \multicolumn{3}{|c|}{ Mandi Gobindgarh } & \multicolumn{3}{|c|}{ Morinda } \\
\hline & $\begin{array}{c}\text { Male } \\
(\mathrm{N}=455)\end{array}$ & $\begin{array}{c}\text { Female } \\
(\mathrm{N}=454)\end{array}$ & $\begin{array}{c}\text { Total } \\
(\mathrm{N}=909)\end{array}$ & $\begin{array}{c}\text { Male } \\
(\mathrm{N}=458)\end{array}$ & $\begin{array}{c}\text { Female } \\
(\mathrm{N}=472)\end{array}$ & $\begin{array}{c}\text { Total } \\
(\mathrm{N}=930)\end{array}$ \\
\hline Obstruction• & $131(28.8)^{*}$ & $119(26.4)^{*}$ & $250(27.5)^{*}$ & $68(14.9)$ & $61(12.9)$ & $129(13.9)$ \\
\hline Mild & $96(21.1)^{*}$ & $92(20.4)^{*}$ & $188(20.7)^{*}$ & $55(12.0)$ & $36(7.7)$ & $92(9.8)$ \\
\hline Moderate & $22(4.8)$ & $13(2.8)$ & $35(3.9)$ & $12(2.6)$ & $19(4.1)$ & $31(3.3)$ \\
\hline Severe & $13(2.8)^{*}$ & $14(3.1)$ & $27(2.9)^{*}$ & $1(0.2)$ & $6(1.3)$ & $7(0.8)$ \\
\hline 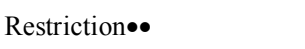 & $132(29.0)$ & $66(14.7)$ & $198(21.7)$ & $111(24.2)$ & $59(12.6)$ & $170(18.3)$ \\
\hline Mild & $106(23.3)$ & $49(10.8)$ & $155(17.0)^{*}$ & $85(18.6)$ & $37(7.8)$ & $122(13.1)$ \\
\hline Moderate & $18(3.9)$ & $17(3.7)$ & $35(3.8)$ & $22(4.8)$ & $20(4.2)$ & $42(4.5)$ \\
\hline Severe & $8(1.8)$ & $0(0.0)$ & $8(0.9)$ & $4(0.9)$ & $2(0.4)$ & $6(0.7)$ \\
\hline
\end{tabular}

Table 3. Prevalence of Respiratory Diseases in "exposed" and the "reference" population, Punjab

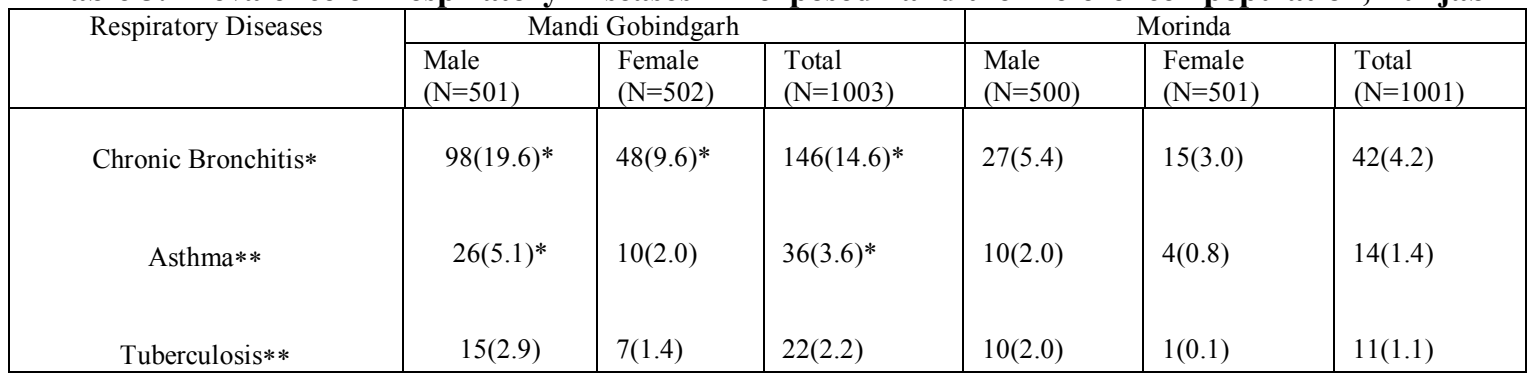

*Between towns $\mathrm{P}<0.05$

* Based on symptoms of cough with expectoration for more than three months in a year for two consecutive years.

** Self reported 
Table 4. Distribution of population characteristics in "exposed" and the "reference" population, Punjab

\begin{tabular}{|l|c|c|}
\hline Variables & $\begin{array}{c}\text { Mandi Gobindgarh } \\
(\mathrm{N}=1003)\end{array}$ & $\begin{array}{c}\text { Morinda } \\
(\mathrm{N}=1001)\end{array}$ \\
\hline Higher socio-economic status & $28(2.8)^{*}$ & $2107(10.7)$ \\
\hline Current Smoking & $318(31.8)^{*}$ & $132(13.2)$ \\
\hline Passive Smoking & $361(36.0)^{*}$ & $444(44.4)$ \\
\hline Biomass fuel use & $705(70.3)^{*}$ & $120(12.0)$ \\
\hline Inadequate lighting & $177(17.6)^{*}$ & $178(17.8)$ \\
\hline Inadequate ventilation & $264(26.3)^{*}$ & $72(7.2)$ \\
\hline Dampness in house & $124(12.4)^{*}$ & $743(74.3)$ \\
\hline Mattress use & $813(81.1)$ & $476(47.6)$ \\
\hline Carpet use & $547(54.5)$ & $954(95.3)$ \\
\hline Presence of insects & $963(96.0)$ & $765(76.4)$ \\
\hline Overcrowding & $697(69.5)$ & $267(26.7)$ \\
\hline Moderate to severe dust exposure & $407(40.7)^{*}$ & $187(18.7)$ \\
\hline Immigrants & $507(50.5)^{*}$ & $0.0(0.0)$ \\
\hline Factory workers & $200(19.9)^{*}$ & \\
\hline
\end{tabular}

*Between towns $\mathrm{P}<0.05$

Table 5. Air pollutants with permissible limits

\begin{tabular}{|l|l|l|l|l|l|}
\hline Ambient air pollutants & Mandi & Morinda & \multicolumn{3}{|c|}{ Permissible Value } \\
\cline { 4 - 6 } & Gobindgarh & & CPCB & WHO & USEPA \\
\hline $\mathrm{PM}_{10}\left(\mu \mathrm{g} / \mathrm{m}^{3}\right)$ & 110.2 & 77.2 & 77 & $83-127$ & 150 \\
$\mathrm{TSP}\left(\mu \mathrm{g} / \mathrm{m}^{3}\right)$ & 890.3 & 291.3 & 500 & - & $75-260$ \\
$\mathrm{NOx}\left(\mu \mathrm{g} / \mathrm{m}^{3}\right)$ & 27.4 & 7.4 & 120 & 200 & 100 \\
$\mathrm{SOx}\left(\mu \mathrm{g} / \mathrm{m}^{3}\right)$ & 29.6 & 8.9 & 120 & 125 & 365 \\
$\mathrm{O}_{3}(\mathrm{ppm})$ & 0.05 & 0.03 & - & 0.10 & 0.12 \\
$\mathrm{CO}\left(\mu \mathrm{g} / \mathrm{m}^{3}\right)$ & 962.9 & 113.9 & 5000 & 10,000 & 10,000 \\
\hline
\end{tabular}

Table 6. Association of residence in poor air quality town with chronic respiratory morbidities

\begin{tabular}{|l|l|l|l|l|}
\hline Variables & Odds Ratio & \multicolumn{2}{l|}{$\begin{array}{l}\text { Significance } \\
\text { P-Value }\end{array}$} \\
\cline { 3 - 5 } & & Lower & 0.001 \\
Cough & 1.59 & 1.21 & 2.21 & 0.003 \\
Dhlegm & 1.56 & 1.17 & 2.07 & $<0.01$ \\
Wheeze & 1.41 & 1.09 & 1.78 & 0.03 \\
Chronic bronchitis & 1.52 & 1.05 & 2.19 & $<0.001$ \\
Asthma & 3.13 & 2.11 & 4.64 & 0.03 \\
Obstructive defects & 2.27 & 1.12 & 4.59 & $<0.001$ \\
Restrictive defects & 1.89 & 1.45 & 2.45 & 0.07 \\
Tuberculosis & 1.66 & 0.98 & 1.66 & 0.5 \\
\hline
\end{tabular}

Logistic regression model include age, sex, socio-economic status, smoking, use of biomass fuel, inadequate ventilation and lighting, dampness in house, mattress or carpet use and overcrowding. 